\title{
Os avessos da romanização em Atenas sob o Império Romano: cultura provincial e modos de integração no decreto IG II' 1035
}

\author{
Beyond Romanization in Roman Athens: provincial culture and \\ modes of integration in the decree IG $/ I^{2} 1035$
}

Fábio Augusto Morales ${ }^{1 *}$

\begin{abstract}
Resumo: Este artigo discute o paradigma da romanização do ponto de vista das províncias gregas do Império romano, tomando como estudo de caso os santuários atenienses mencionados no decreto para restauração de santuários da Ática (IG $\|^{2}$ 1035), de época augustana. Após uma breve discussão acerca das reviravoltas historiográficas do paradigma da romanização, o artigo explora as relações entre memória, cultura e poder implicadas nas restaurações, argumentando que mais do que decidir entre explicações baseadas nas ideias de "resistência" ou "submissão" cultural, é preciso voltar a atenção para a sobreposição de diferentes modalidades de integração.
\end{abstract}

\begin{abstract}
This paper discusses the 'Romanization debate' from the viewpoint of the Greek-speaking Roman provinces, taking as a case study the Athenian sanctuaries mentioned in the 'Augustan' decree for the restoration of Attic sanctuaries (IG $\|^{2}$ 1035). After a brief discussion on the twists of the Romanization paradigm, the paper explores the relations between memory, culture and power implicated in the restorations, arguing that, rather than decide between 'cultural resistance' or 'submission' explanations, we should focus on the overlapping modalities of integration.
\end{abstract}

Palavras-chave: Atenas augustana; Romanização; Decreto IG II 1035.

\section{Keywords:}

Augustan Athens; Romanization; Decree IG II 1035. 


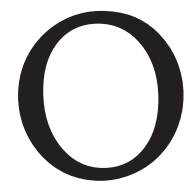
objetivo deste artigo é apresentar uma contribuição ao "debate da romanização", tomando como referência a produção do espaço urbano ateniense durante o principado de Augusto. Após uma série de reviravoltas acadêmicas, o termo, conceito ou espectro da romanização volta a rondar os estudos sobre as culturas provinciais romanas. Neste texto, apresento brevemente as especificidades do debate da romanização da Grécia, para então discutir com mais detalhe o decreto registrado na inscrição IG II 1035, célebre por suas menções às restaurações de santuários na Ática, datado do período augustano. Após a análise da lógica subjacente às restaurações, o artigo conclui com a discussão dos sentidos destas intervenções para uma história dos processos de integração mediterrânicos sob dominação romana.

\section{A romanização da Grécia e os paradigmas da História Antiga}

Erigida sob a égide do romanocentrismo, ou seja, estruturada pela conversão metonímica da história da cidade de Roma e seus imperadores em história do Império Romano (GUARINELLO, 2010), a historiografia do Império Romano acompanhou os movimentos acadêmicos mais amplos relacionados aos dilemas ético-políticos da experiência imperialista europeia. Assim, até a erosão dos impérios europeus no pós1945, paradigmas fundados na hierarquização das culturas poderiam ser engajados na explicação das rupturas ou continuidades culturais das províncias imperiais: culturas superiores se imporiam às culturas inferiores, respeitando as previsões da metanarrativa que orientava a história na direção da formação e expansão da civilização ocidental. No caso do Império Romano, tal explicação se confrontava com a clivagem entre as diferentes culturais provinciais divididas em dois blocos: províncias ocidentais, "bárbaras"; e províncias orientais, "gregas". No Ocidente, a superioridade da cultura latina se impôs sobre as culturas bárbaras gaulesas, ibéricas, bretãs, compondo a formulação clássica da "romanização". No Oriente, pelo contrário, a superioridade da cultura grega, mesmo sobre a cultura latina, resultaria na manutenção dos traços culturais da helenidade, a despeito da submissão político-militar. Mais do que isso, a própria cultura latina se submeteria à cultura da Grécia, que mesmo "capturada [,] capturou seu feroz vencedor e instituiu as artes no agreste Lácio" (Horácio, Epistolae, 2, 1, 156), conforme a célebre formulação horaciana que se tornaria o lema de uma historiografia da resistência cultural grega. ${ }^{1}$

\footnotetext{
${ }^{1} \mathrm{O}$ debate bibliográfico sobre a romanização é extenso, assim como numerosas são as tentativas de síntese, quase onipresentes nas introduções de trabalhos dedicados ao tema das culturas provinciais. Tentativas recentes de apreensão do movimento geral do debate podem ser encontradas em Silva (2011), Morales (2014), Bina (2015); novas perspectivas são debatidas com profundidade no primeiro número do volume 21 da revista Archaeological Dialogues, a partir do artigo de Versluys (2014).
} 
A crise radical das metanarrativas eurocêntricas promovida pelo processo de descolonização e a afirmação das perspectivas pós-coloniais nas universidades ocidentais, impulsionando a problematização da identidade e da cultura nas mais diversas situações e instituições, afetou também a historiografia das culturas provinciais romanas. Paulatinamente, a partir dos anos 1970, afirmaria-se uma historiografia que enfatizaria as diversas formas de resistência à romanização nas províncias ocidentais, num espectro de respostas culturais que iria do multiculturalismo ao hibridismo, reforçando a centralidade das situações concretas que engajariam diferentes identidades. Para as províncias orientais, entretanto, somente na década de 1990 surgiriam os primeiros estudos que relativizariam a suposta resistência cultural (MORALES, 2014). A produção de S. Alcock pode ser tomada como paradigmática deste movimento. Se num primeiro momento a manutenção dos traços culturais gregos era contraposta ao impacto radical do Império Romano nas "paisagens" sociais gregas (ALCOCK, 1993), a busca pelas resistências (ALCOCK, 1997) levou a uma "arqueologia da memória", que enfatizava as ambiguidades das escolhas culturais gregas diante das expectativas romanas (ALCOCK, 2001; 2002). No limite, a adoção de traços culturais gregos poderia ser interpretada como uma forma de submissão àquelas expectativas: os romanos buscavam a Grécia clássica, e era isto que os gregos competiam para oferecer. Desse modo, enquanto o Ocidente era historiograficamente desromanizado, o Oriente era romanizado na medida em que se helenizava.

Na passagem da década de 2000 para 2010, o quadro se tornou ainda mais complexo. Wallace-Hadrill (2008), em seu Rome's Cultural Revolution, defenderia a tese de que o paralelo cultural da "revolução romana" de Syme, ou seja, a ascensão das elites italianas nas estruturas políticas de Roma, implicou a adoção estratégica de traços culturais gregos: italianos helenizados refundaram, com técnicas de saber gregas, a relação dos romanos com sua própria identidade. Dito de um modo talvez demasiadamente direto: os italianos helenizaram Roma, que se tornou romana por meio desta helenização. A aplicação deste modelo para a análise da cultura provincial grega foi realizada alguns anos mais tarde por Spawforth, em seu Greece and the Augustan cultural revolution (SPAWFORTH, 2012): segundo o autor, na medida em que as expectativas romanas acerca da cultura grega eram parte de um processo de helenização de Roma, a romanização da Grécia operou por meio do reforço de determinada helenidade dos gregos, aquela ditada por Roma (e, mais ainda, pela elite imperial, como a personalização da "revolução cultural" no título claramente antecipa). Os romanos se tornavam romanos por meio da helenização; os gregos se tornavam gregos por meio da romanização. 
A década de 2010, ainda, veria a adição de mais uma complicação. Após décadas de relativo desprezo à história das pólis gregas nos períodos helenísticos e romanos - a despeito dos esforços de pioneiros como L. Robert e Ph. Gauthier -, a "pólis pós-clássica" tornou-se objeto de uma crescente bibliografia, que trabalha, a partir do abundante material epigráfico, as diferentes soluções que as cidades gregas encontraram diante de novos desafios. Longe de significar a "decadência da pólis", os períodos helenístico e romano abrigam processos históricos que demonstram a vitalidade das instituições cívicas, tais como o evergetismo de monarcas e notáveis locais e regionais, a ampliação das redes agonísticas, a multiplicação de rituais cívicos, a intensificação da transformação urbana, etc. (VAN NIJF; ALSTON, 2011). Assim, a consideração da agência das populações locais diante da "romanização/re-helenização" aumenta a complexidade da história das culturas das províncias gregas sob o Império.

Tais reviravoltas levam a uma aporia: na medida em que a resistência cultural poderia significar submissão, qualquer intervenção mais ou menos associada a Roma poderia ser interpretada simultaneamente como resistência e como submissão. Tomando o caso melhor documentado, qual seja, as intervenções urbanas em Atenas no início do principado, é eloquente o modo como os debates da historiografia específica assumiram um movimento pendular, ora reforçando o peso das tradições locais, ora reforçando o peso das ligações com Roma, em cada uma das intervenções conhecidas. Tal movimento pendular tem uma dinâmica própria, e responde às agendas ético-políticas e científicas de cada pesquisador. Porém, o fato é que em cada intervenção há indícios de tradição local e de resposta à expectativa romana; além disso, não há fontes diretas para se determinar o modo como tais intervenções foram recebidas pelos diferentes grupos sociais em diferentes períodos, cuja agência é parte da construção histórica do sentido das intervenções (MORALES, 2013; 2016).

Não se diz com isso que o debate é estéril; pelo contrário, a cada movimento do pêndulo novos indícios são aduzidos a um quadro cada vez mais complexo. No entanto, se a evidência permite a formulação de respostas opostas à mesma questão, nos parece que é a questão que deve ser reformulada. Neste sentido, para além da busca pelo significado último das intervenções, parece ser mais interessante analisar o modo como estas intervenções participam de processos mais gerais, que, não obstante, se realizam por meio dos casos específicos. Aqui, proponho uma exploração do problema da integração entre diferentes modalidades de integração concorrentes ou associadas, que se articulam na produção das transformações no espaço urbano ateniense no final do século I a.C., produzindo-se um regime de espacialidade específico que denomino antiquarianismo 
urbano. Entre as diversas intervenções espaciais em Atenas datadas do período, tomo aqui aquelas mencionadas na célebre inscrição IG II 1035.

\section{O decreto para restauração dos santuários: IG II $1035^{2}$}

A maior parte das intervenções espaciais augustanas são conhecidas por meio de vestígios arqueológicos e poucas são as referências literárias e epigráficas - os limites e possibilidades para sua interpretação derivam, em grande parte, do caráter esparso da documentação. Ironicamente, a única inscrição que concentra informações sobre um grande conjunto de intervenções construtivas não faz, para desespero do pesquisador, qualquer menção clara àquelas conhecidas arqueologicamente. O decreto da restauração dos santuários (IG II 1035) lista cerca de 80 sítios, entre santuários (iعpó), recintos sagrados

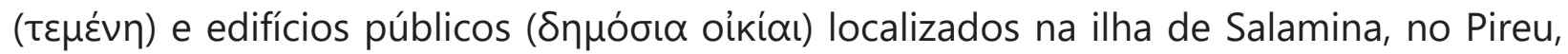
no interior da Ática e em Atenas e arredores. O estado fragmentário da inscrição impede uma determinação precisa da datação e da listagem integral dos sítios relacionados, mas a expressiva bibliografia dedicada a este documento construiu bases importantes para sua interpretação (CULLEY, 1975; 1977; SHEAR JR., 1981; BALDASSARRI, 1998, p. 242-246; SCHMALZ, 2007-2008; 2009, p. 282; SPAWFORTH, 2012, p. 107-112). Aqui, serão tratados apenas os sítios intramuros, quais sejam: os santuários das jacintides, do herói Stratego, da Boa Fortuna, da Glória e Concórdia, de Serápis, de Zeus Olímpio e de Teseu, além da Dedicação Atálida, do antigo Bouleuterion e do Horologium.

A inscrição é composta por três textos relacionados. O primeiro é o decreto instituído pelo demos que decide pela restauração dos santuários e precintos dos deuses e heróis para a "glória do demos" ( $\delta$ ć $\alpha \nu$ toû $\delta$ ń sua implementação, tendo como protagonistas o arconte-rei, o general dos hoplitas e

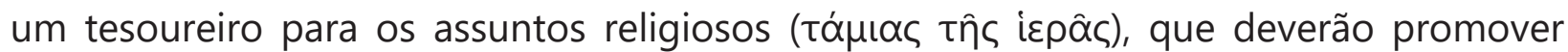
a restituição das terras sagradas ocupadas por privados aos santuários, a realização de rituais purificatórios, e a restauração de edifícios, monumentos e objetos sagrados. 0 terceiro é um catálogo dos sítios que receberam a ação restauradora. O general dos hoplitas mencionado é certo Metrodoros, filho de Xenon, do demos de File, que deveria executar o projeto ao lado do arconte-rei Mantias, filho de Dositheos, de Maratona. Estes dois personagens não são mencionados em outras fontes, o que tornou a datação do decreto particularmente complexa - as sugestões variaram do período pós-86 ao século II, ainda que a datação augustana tenha se tornado hegemônica, em função da lógica

${ }^{2}$ A discussão a seguir é uma atualização daquela apresentada na tese do autor (cf. MORALES, 2015, p. 336-344). 
subjacente ao programa. Recentemente, G. Schmalz ofereceu uma solução com bases prosopográficas mais seguras, identificando Mantias como filho de Dositheos, membro do genos dos Kerykes, sacerdote eleusino e arconte-rei do início do Principado, e datando a magistratura de Metrodoros de pouco tempo depois de seu exercício como arconteepônimo, que ocorreu pouco tempo depois de 10/9 (SCHMALZ 2007-2008, p. 15; 2009, p. 282); assim, a proposta de datação no final do século I a.C. e início do I d.C. se torna a mais plausível.

O catálogo está incompleto, mas os trechos preservados permitem uma aproximação das lógicas envolvidas nas restaurações. Os sítios e monumentos a serem restaurados se referem, em sua quase totalidade, a importantes eventos míticos ou históricos do passado ateniense, em particular ao conflito entre Mégara e Atenas pela posse de Salamina - no qual Ajáx e seu filho Eurisaces (que ofereceu a ilha em troca da cidadania ateniense) ocupam papel central -, as Guerras Médicas, a guerra do Peloponeso e a resistência à ocupação macedônica. A comemoração do passado local é coerente com as intervenções do período augustano, e a participação de Mantias é indicativa de uma proximidade maior ao próprio Augusto. O pai de Mantias, Dositheos, exerceu uma série de cargos sacerdotais eleusinos na época de Temístocles de Hagnous, sacerdote eleusino responsável pela segunda iniciação de Augusto, em 19; como membro do genos dos Kerykes e filho de um importante sacerdote, é possível que Mantias tenha tido fortes relações com os mistérios de Elêusis e com personagens mais ou menos ligadas ao princeps, o que explicaria sua ascensão a arconte-rei no momento da implementação deste grande projeto de restauração.

Os sítios intramuros listados no decreto são: ${ }^{3}$

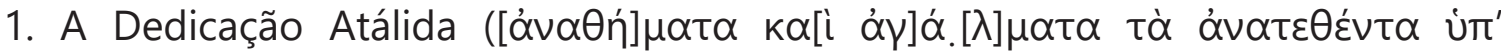

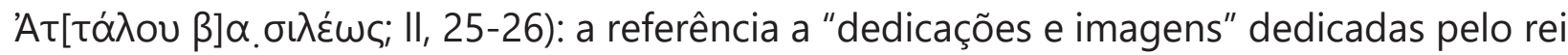

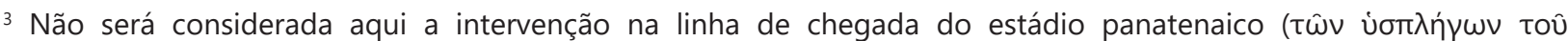

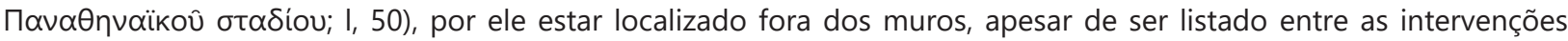
intramuros. De qualquer modo, vale destacar um fator pouco observado pela bibliografia: é atestada a utilização do estádio panatenaico como espaço para assembleias no ano de 188/7 (IG II2 893) e realização das reuniões do Conselho nos anos de 229/8 (Agora I 7181), 216/5 (IG II² 794), 192/1 (IG II² 916) e 38/7 (IG II² 1043), no mesmo período em que as assembleias tendem a ocorrer regularmente no teatro de Dioniso e não mais na Pnyx. Neste sentido, ainda que o estádio não seja enquadrado tão facilmente na categoria de "santuário", a restauração pode estar associada a seu uso como sede de reuniões políticas, que subentendiam rituais e sacrifícios (para a assembleia: Ésquines, 1, 23 e 2, 158; para o Conselho, SEG 40, 289; entre outros), para além da utilização do estádio nos festivais do calendário religioso da cidade

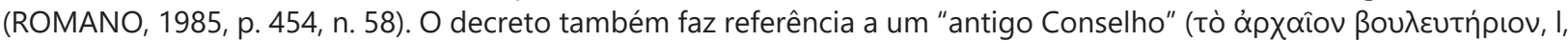

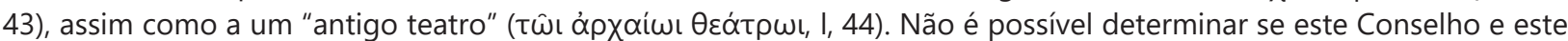
teatro são o conjunto conhecido como Metroon a partir do século ll e o teatro de Dioniso, ou se são edifícios de função semelhante localizados no Pireu, dado que estas linhas do catálogo estão no trecho dedicado às intervenções no porto. A ausência de vestígios de intervenções de época augustana no Metroon e no teatro de Dioniso corrobora a segunda hipótese, e por isso estas intervenções não serão discutidas na presente listagem.
} 
Átalo certamente se referem à Dedicação Atálida mencionada por Pausânias $(1,25,2)$. Sua posição no decreto - no trecho dedicado a detalhar os procedimentos para a restauração e não no catálogo de intervenções - é peculiar, mas pode ser entendido pela "função" da

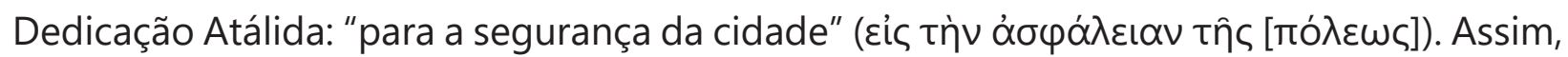
não está claro se a Dedicação Atálida recebeu trabalhos de restauração, ou se servia de modelo para as restaurações a serem realizadas. De qualquer modo, está claro que a Dedicação Atálida tinha um sentido ritual na época do decreto, o que pode significar a permanência deste significado já instituído na dedicação (MORALES, 2015, p. 102-123).

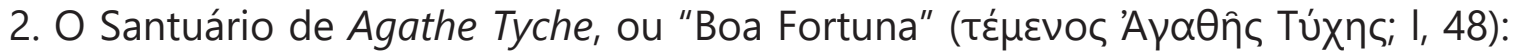
seguramente localizado na Colina das Musas, próximo às muralhas no limite sudeste da cidade; o santuário foi restaurado em 335/4, na época de Licurgo, e recebeu um grande sacrifício no final do século IV "para garantir a segurança do demos dos atenienses" (SEG 44, 42, 29-30), o que possivelmente estava associado à constante ameaça macedônica à democracia e à população ateniense, coerente com a menção de Pausânias às sepulturas públicas de 13 atenienses mortos na colina das Musas no conflito com as tropas macedônicas, no século III (Pausânias, 1, 29, 13).

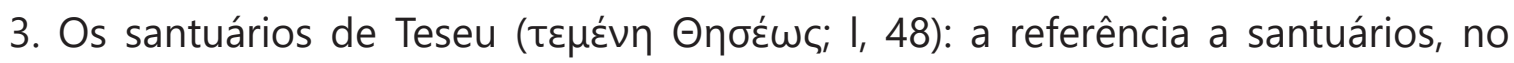
plural, indica claramente que não se trata apenas do Theseion construído por Címon no século $\mathrm{VI}$, mas dos diversos santuários de Teseu na Ática; no entanto, dificilmente não seria incluído o Theseion urbano. Sua localização ainda não foi determinada, mas provavelmente estava situado ao norte/nordeste da acrópole, próximo ao ginásio de Ptolomeu. Além de heroon com o túmulo de Teseu, rei responsável pelo sicenismo na Ática, o Theseion era decorado com pinturas representando uma centauromaquia, uma amazonomaquia, e um episódio da expedição de Teseu a Creta (Pausânias, 1, 17, 2). Assim, a comemoração anti-bárbara é fundamental neste santuário, e em particular a celebração da defesa contra a invasão bárbara, seja no caso da amazonomaquia, na qual Teseu foi protagonista, seja na maratonomaquia, à qual Teseu era diretamente associado em uma pintura na Stoa Pintada, na ágora (Pausânias, 1, 15, 3).

4. O santuário das Jacintides (Yakívөıov; I, 52): as jacintides são associadas, em diferentes tradições, a jovens imoladas para a defesa da cidade; a principal versão, provavelmente, é aquela que aparece na peça Erechtheus, de Eurípides (frag., 47, 60, 27, 65,67-87), na qual as jacintides são as filhas do rei Erechtheus, sacrificadas pelo pai como forma de vencer a guerra contra Elêusis. No período histórico, sacrifícios eram praticados pelo exército ateniense antes de ações militares. O santuário estava ligado não apenas à proteção da cidade, mas também à construção de sua composição territorial, cujas implicações religiosas, no caso de Elêusis, são claras: a imolação das jovens seria 
fundamental para a anexação do santuário de Deméter, base da percepção de Atenas como berço da agricultura; a presença de um membro do genos dos Kerykes como arconte-rei, responsável pelo projeto, pode estar associada à escolha deste santuário.

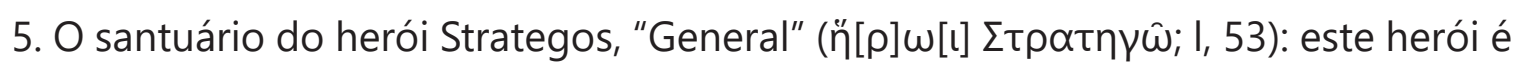
conhecido apenas por meio de dedicações encontradas na ágora, e somente a partir de 200 (ROSTROFF, 1978, p. 205); é provável que seu altar estivesse localizado no Strategion, ao sul do Tholos (WYCHERLEY, 1957, p. 176). É tentador sugerir que a construção do propileu dórico do Strategion da ágora esteja vinculada ao decreto de restauração, o que poderia ser associado, além dos valores militares inerentes ao santuário, ao prestígio da magistratura dos generais dos hoplitas, especialmente quando se considera que eles eram os responsáveis, ao lado do arconte-rei, pela execução do decreto.

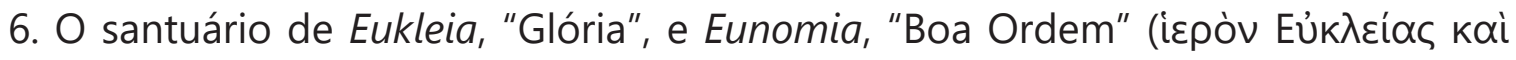
Eúvouíac; I, 53): seja como sede do culto de Ártemis Eukleia (SCHMALZ, 2007-2008, p. 44), ou de abstrações divinizadas (Eunomia, filha de Têmis em Hesíodo, Teogonia, 902; cf. WYCHERLEY, 1957, p. 58), este santuário era diretamente associado à vitória sobre os persas: seu culto foi instituído logo após a batalha de Plateia, remetendo ao culto de Ártemis realizado no local; sua localização não é conhecida, ainda que existam referências para seu culto na ágora, talvez na Kolonos Agoraios (SCHMALZ, 2007-2008, p. 44) ou mesmo no Tholos (WYCHERLEY, 1957, p. 58-59). O sacerdote do culto tinha assento inscrito para si no teatro de Dioniso, o que demonstra o prestígio do culto.

7. O "ginásio" ( $\pi \alpha \lambda \alpha i ́ \sigma \tau \rho \alpha v ; ~ I, 54)$ : a referência a uma palestra no decreto, infelizmente, se faz no final de uma frase perdida; não possível, portanto, determinar a qual ginásio esta palestra correspondia, nem se a própria palestra ou algo relacionado a ela foi objeto de intervenção. A sugestão de que se tratava do complexo do Ptolemaion, que incluía, provavelmente, o santuário de Diógenes, faria sentido considerando o caráter anti-macedônico de determinadas restaurações; mas o caráter lacunar da inscrição impede qualquer avanço nesse sentido.

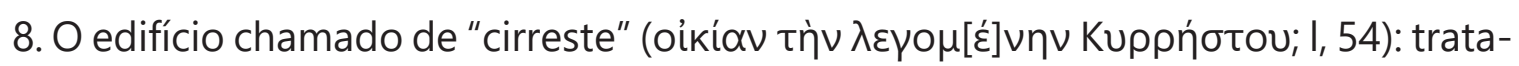
se do Horologium construído por Andrônico de Cirro, no século II, a leste do que seria a ágora romana. Sua inclusão no plano de restauração deve estar associada a necessidades práticas de restauração, dada a utilização do edifício como relógio solar e hidráulico; não há elementos claros para associar tal intervenção a santuários ou significados religiosos.

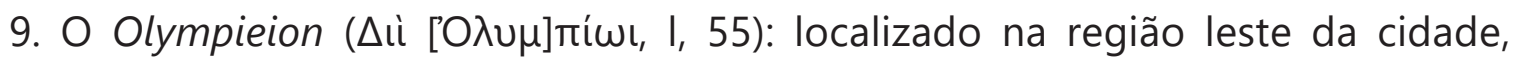
foi objeto da ação construtiva augustana, e estava associado, para além das origens tirânicas, ao evergetismo sírio patrocinado por Antíoco IV. A densidade religiosa do santuário, repleto de cultos de caráter pan-helênico, associada à secular e então ainda 
incompleta construção, justificaria sua inclusão no projeto de restauração - relativa aos terrenos diante do santuário - possivelmente associado às intervenções augustanas projetadas - e eventualmente realizadas, ainda que parcialmente - pelos "reis amigos" (Suetônio, Augusto, 60).

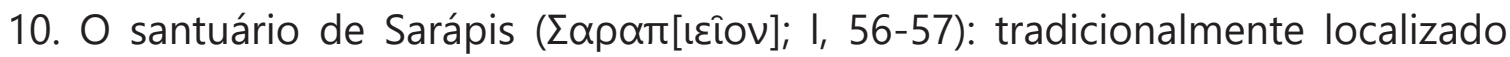
pelos estudiosos na área sob a atual catedral metropolitana, foi construído provavelmente por Ptolomeu III (Pausânias, 1, 18, 4), provavelmente em cerca de 220 (MIKALSON, 1998, p. 276); a instituição deste culto greco-egípcio certamente estava associada à proteção garantida pela monarquia lágida à liberdade ateniense contra a macedônia.

A comemoração do passado militar ateniense, em particular do ponto de vista da proteção e defesa da cidade, bastante claro nas restaurações em Salamina e no Pireu mencionadas no início do catálogo, estão presentes nas restaurações intramuros: as guerras do tempo mítico estão presentes na restauração do santuário das Jacintides (Elêusis) e de Teseu (amazonas, Creta); as guerras médicas estão presentes nos santuários de Teseu (Maratona) e da Glória e Boa Ordem (Platéia); as guerras macedônicas estão presentes nos santuários da Boa Fortuna (séc. III?), no santuário de Sarápis (pós-229?) e na Dedicação Atálida (200?), e talvez na "palestra", caso ela esteja relacionada ao Ptolemaion e/ou Diogeneion (pós-229); é plausível que o santuário do herói Strategos estivesse relacionado à cultura militar ateniense como um todo. As intervenções não diretamente relacionadas às guerras atenienses, tais como o santuário de Zeus Olímpio e o Horologium (e talvez a "palestra") podem ser interpretadas em termos de oportunidade construtiva: o Horologium poderia ser objeto das intervenções por problemas relacionados à sua funcionalidade, enquanto as intervenções no santuário de Zeus Olímpio estariam relacionadas ao interesse constituído entre os evergetas da época em função da já secular história construtiva do templo. A hipótese de que alguns santuários podem ter sido escolhidos em função de um eventual enfraquecimento de seus cultos é indicada pela transposição do templo de Ares e pela reutilização de elementos arquiteturais de outros templos, em particular os de Atena e Poseidon, no Sounion; no entanto, a recorrência de santuários ligados à memória militar ateniense não deixa dúvidas de uma lógica dominante no programa.

O programa ateniense de restauração de santuários não é caso único: o paralelo evidente é a grande restauração de santuários em Roma levada a cabo por Augusto (GROS, 1976). Para além das semelhanças de quantidade e tipologia (cerca de 80 santuários), os dois projetos apresentam um grande paralelismo na preocupação antiquária: no caso ateniense, a mitografia e a atidografia são visíveis na escolha dos sítios, intimamente ligados à tradição mítica e histórica ateniense, e que terá ecos em autores como Plutarco 
e Pausânias; no caso romano, entre os eruditos convocados a participar do processo de seleção dos santuários a serem restaurados estava Tito Pompônio Ático, nos últimos anos de sua vida, responsável direto pela escolha do templo de Júpiter Feretrius como objeto da restauração augustana (Nepos, Ático, 20). No Oriente grego, há evidências para projetos semelhantes - em menor escala - na Messênia e em Argos, na Grécia, Éfeso e Cime, na Ásia Menor (SCHMALZ, 2007-2008, p. 26-27; SPAWFORTH, 2012, p. 211-232), todos eles associados direta ou indiretamente a Roma e aos membros da família imperial (seja como financiadores, seja como homenageados).

Sem negligenciar completamente as implicações materiais do decreto-em particular a questão das terras sagradas - Schmalz (2007-2008, p. 11) propõe uma interpretação geral para o programa restaurador: trata-se de um episódio da construção de um idioma comum às cidades gregas para a comunicação cultural entre elas e com as autoridades romanas no início do principado, no qual a memória cultural grega desempenharia um papel central. Spawforth (2012, p. 107-112) desenvolveu esta interpretação a partir da ênfase nos processos de seleção do passado a ser lembrado: os atenienses selecionaram os sítios não em função simplesmente do "orgulho local", mas também em função das expectativas romanas em relação ao passado grego. Assim, a atenção dada aos equipamentos náuticos do Pireu era contraditória com a então irrelevante marinha ateniense; no mesmo sentido, a referência à guerra do Peloponeso, que resultou na traumática derrota, só faria sentido para uma audiência ávida pela história grega, e não somente os sucessos atenienses. ${ }^{4}$

A restauração dos santuários atenienses seria, dessa forma, um dos fatores mais importantes da romanização de Atenas. No entanto, é possível levantar uma série de ressalvas a esta interpretação. Em primeiro lugar, a celebração das Guerras Médicas como referência central da identidade grega - e ateniense - não pode, de maneira alguma, ser tomada como uma invenção augustana: a intensa construção na acrópole na época de Péricles e nos séculos seguintes, em particular no final do IV e início do II a.C., demonstram com clareza o modo como as Guerras Médicas já eram um elemento estrutural da identidade local e da comunicação cultural de Atenas com as potências e centros culturais mediterrânicos. A valorização das Guerras Médicas por Roma é parte deste processo de consolidação de um discurso autoreferenciador grego que tem, no período helenístico, sua formação em âmbito mediterrânico: é neste momento, em particular com Alexandre

\footnotetext{
${ }^{4} \mathrm{O}$ sucesso do programa cultural das restaurações, centrado especialmente na celebração das Guerras Médicas, seria evidente, por exemplo, no evergetismo praticado por C. Júlio Nicanor, um evergeta sírio que se tornaria general dos hoplitas em Atenas, e que teria recebido o título de "Novo Temístocles", provavelmente por ter restaurado a Atenas a posse de territórios em Salamina (SCHMALZ, 2007-2008, p. 16-17).
} 
e com os reis atálidas, que a memória local anti-bárbara ateniense se torna um "idioma" para a diplomacia, tanto para a segurança de Atenas quanto para a afirmação de novas potências. Em segundo lugar, a prática de restauração dos santuários é atestada em diversos momentos na história ateniense, em particular nas reformas de Licurgo, no século IV a.C.; provavelmente não por acaso, Temístocles de Hagnous, um dos personagens centrais da política e da religiosidade ateniense na época de Augusto, era descendente tanto do vencedor dos persas em Salamina, quanto, por meio da esposa, do legislador do século IV a.C. (SPAWFORTH, 2012, p. 116). Não há indícios claros para a participação de Temístocles no programa da restauração, mas o prestígio mantido pela família e pelo genos de Licurgo (os Eteobutadais) no período helenístico e romano vão na direção de uma retomada de sua política religiosa de restauração de santuários e práticas rituais (MIKALSON, 1998, p. 11-45; 241; 307). Em síntese: as práticas e as ideias pressupostas na restauração dos santuários já existiam no período anterior, e faziam parte do repertório disponível para sua nova execução.

Um aspecto particularmente interessante do decreto é a sua ênfase nas questões fundiárias. O decreto é explícito: visa, além da restauração de edifícios, à restauração da propriedade das terras sagradas invadidas por agentes privados. Dois santuários são centrais para este processo: os santuários de Teseu e de Atena Polias, que detinha terras não somente nos arredores de Atenas, como também em outras regiões da Ática. As implicações desta restauração fundiária são enormes: trata-se de uma recomposição da estrutura da propriedade da terra - para cujas grandezas não temos, infelizmente, documentação - que passa a ter como agentes centrais os sacerdotes encarregados da manutenção de seus respectivos santuários. Não por acaso, o período augustano assiste a processos de recomposição dos gene tradicionais, em particular os Kerykes (de Temístocles de Hagnous) e o Eteobutadai (de Areios de Peânia). Diversos sacerdócios se tornam vitalícios, tais como o de Apolo Délio ou o de Asclépio, o que significa que o sacerdote será o administrador para toda a vida de propriedades de terra dos santuários. ${ }^{5} \mathrm{~A}$ raridade de documentação relativa à propriedade fundiária ateniense na época augustana impede a construção de hipóteses mais seguras, mas é tentador pensar que a afirmação da aristocracia fundiária ateniense passa, neste período, por uma reconfiguração: os sacerdócios se tornam mecanismos fundamentais para a obtenção e acumulação de propriedade, que se não é privada - posto que pertencente ao santuário - é vitalícia, e

\footnotetext{
${ }^{5}$ Sobre a administração pública e clânica das terras sagradas, cf. Papazarkadas (2011, especialmente p. 170-190). Sobre as estelas com inscrições de limite das terras sagradas, cf. Lalonde (1991), que cita dois horoi de época romana relativos ao temenos de Atena Polias, gerido pelo genos dos Etebutadais ( $\mathrm{H} 23-\mathrm{H} 24)$.
} 
permanentemente ligada ao genos, daí a importância econômica da atualização das listas de membros, das quais sobreviveram dois dos principais gene áticos.

Além da questão fundiária, a própria restauração arquitetural dos santuários, a ser capitaneada pelo arconte-rei e pelo general dos hoplitas, demonstra o fortalecimento destas magistraturas do ponto de vista da produção do espaço urbano. A participação do arconte-rei em intervenções urbanas atenienses no período augustano é atestada apenas no decreto IG II 1035 , o que se explica pela fundamental importância das corretas práticas rituais no reestabelecimento dos santuários e seus cultos; a participação do general dos hoplitas, por outro lado, é bem atestada em outras intervenções (MORALES, 2015, p. 259-344), o que indica que esta magistratura se tornou a chave para a atividade construtiva ateniense - ecoando assim as épocas de Péricles e de Licurgo. O decreto de restauração dos santuários áticos, deste ponto de vista, é uma etapa fundamental dos conflitos relacionados ao controle da produção do espaço urbano ateniense; a ambiguidade local/imperial, renovação/restauração, presente em praticamente todas as intervenções analisadas, comparece aqui de maneira particularmente associada às magistraturas, pontos de ligação entre elites imperiais e locais.

\section{Conclusão}

O decreto de restauração dos santuários registrado na inscrição IG II2 1035 é tanto o produto quanto o vetor de diferentes modalidades de integração, cada uma tendo diferentes articulações espaciais e temporais. A integração político-militar da dominação imperial romana sobre o Mediterrâneo sobrepõe-se à integração cultural da memória anti-bárbara ateniense, ela própria parte da história de longa duração das reconfigurações do "repertório bárbaro" da cultura grega (VLASSOPOULOS, 2013). A articulação entre estas duas modalidades de integração no contexto do Principado, longe de significar exclusivamente a resistência ou a submissão à romanização, reconfigura as relações entre as elites locais com as instituições políades (como os gene e os sacerdócios) e com as redes de elites imperiais. Trata-se, pois, de uma etapa da construção do Mediterrâneo romano, processo de integração complexo, que não se limita às dualidades de um debate historiográfico datado, como o da romanização. 


\section{Referências}

\section{Documentação textual}

HORÁCIO. Orazio, Tutte le poesie. Torino: Einaudi, 2009.

PAUSANIAS. Description de la Gréce. Paris: Les Belles Lettres, 2002.

SUETONIUS. Vies des douze Césars. Paris: Les Belles Lettres, 1961.

\section{Obras de apoio}

ALCOCK, S. Archaeologies of the Greek past: landscape, monuments, and memories. Cambridge: Cambridge University Press, 2002.

ALCOCK, S. The reconfiguration of memory in the Eastern Roman Empire. In: ALCOCK,

S. et al (Ed.). Empires: perspectives from Archaeology and History. Cambridge: Cambridge University Press, 2001, p. 323-350.

ALCOCK, S. Roman Greece: landscape of resistance? In: MATTINGLY, D. (Ed.). Dialogues in Roman imperialism: power, discourse, and discrepant experience in the Roman Empire. Portsmouth: Journal of Roman Archaeology, 1997, p. 103-15.

ALCOCK, S. Graecia capta: the landscapes of Roman Greece. Cambridge: Cambridge University Press, 1993.

BALDASSARRI, P. Sebastoi soteri: edilizia monumentale ad Atene durante il Saeculum Augustum. Roma: G. Bretschneider, 1998.

BINA, T. A busca pela "originalidade religiosa" nas Gálias no período imperial. Romanitas, n. 5, p. 78-92, 2015.

CULLEY, G. The restoration of sanctuaries in Attica: IG II2 1035. Hesperia, v. 46, p. 282-298, 1977.

CULLEY, G. The restoration of sanctuaries in Attica: IG II 1035 . Hesperia, v. 44, p. 207-223, 1975.

GROS, P. Aurea templa: recherches sur l'architecture religieuse de Rome à l'èpoque d'Auguste. Rome: École Française de Rome, 1976.

GUARINELLO, N. Ordem, integração e fronteiras no Império Romano. Um ensaio. Mare Nostrum, v. 1, p. 113-127, 2010.

LALONDE, G. Horoi. In: LALONDE; G.; LANGDON, M.; WALBANK, M. (Ed.). Inscriptions: horoi, poletai records, leases of public lands. Princeton: The American School of Classical Studies, 1991, p. 51.

MIKALSON, J. Religion in Hellenistic Athens. Berkeley: University of California Press, 1998. 
MORALES, F. Edifícios como fonte histórica: o caso do templo de Ares na ágora de Atenas (século I a.C.). Revista de Fontes, v. 5, n. 2, p. 17-30, 2016.

MORALES, F. Atenas e o Mediterrâneo romano: espaço, evergetismo e integração (200 a.C. - 14 d.C.). Tese (Doutorado em História) - Programa de Pós-Graduação em História Social da Universidade de São Paulo, São Paulo, 2015.

MORALES, F. Graecia capta, novamente: considerações sobre os limites da nova romanização da Grécia. Revista do Museu de Arqueologia e Etnologia, n. 18, p. 9198, 2014.

MORALES, F. Propaganda, resistência, propaganda... Um balanço dos estudos sobre as intervenções urbanas em Atenas na época de Augusto (1927-2012). História \& Cultura, v. 2, n. 3, p. 109-135, 2013.

PAPAZARKADAS, N. Sacred and public land in Ancient Athens. Oxford: Oxford University Press, 2011.

ROMANO, D. The Panathenaic Stadium and Theater of Lykourgos: a re-examination of the facilities on the Pnyx Hill. American Journal of Archaeology, v. 89, n. 3, p. 441-454, 1985.

ROSTROFF, S. An anonymous hero in the Athenian Agora. Hesperia, v. 47, n. 2, p. 196-209, 1978.

SCHMALZ, G. Augustan and Julio-Claudian Athens: a new epigraphy and prosopography. Leiden and Boston: Brill, 2009.

SCHMALZ, G. Inscribing a ritualized past: restoration decree IG $\|^{2} 1035$ and cultural memory in Augustan Athens. Eulimene, v. 8-9, p. 9-46, 2007-2008.

SHEAR JR., L. Athens: from city-state to provincial town. Hesperia, v. 50, n. 4, p. 356-77, 1981.

SILVA, B. Romanização e os séculos XX e XXI: a dissolução de um conceito. Mare Nostrum, n. 2, p. 57-75, 2011.

SPAWFORTH, A. Greece and the Augustan cultural revolution. Cambridge: Cambridge University Press, 2012.

VAN NIJF, O.; ALSTON, R. Political culture in the Greek city after the Classical Age. Leuven, Paris and Walpole: Peeters, 2011.

VERSLUYS, M. 'Understanding objects in motion. An archaeological dialogue on Romanization', Archaeological Dialogue, v. 21, n. 1, p. 1-20, 2014.

VLASSOPOULOS, K. Greeks and barbarians. Cambridge: Cambridge University Press, 2013. WALLACE-HADRILL, A. Rome's cultural revolution. Cambridge: Cambridge University Press, 2008.

WYCHERLEY, R. E. Literary and epigraphical testimonia. Princeton: The American School of Classical Studies, 1957. 